PUBLISHED IN MARINE GEOLOGY, V. 258, PP. 115-125 (2009). (c ELSEVIER SCIENCE BV.

DOI:10.1016/J.MARGEO.2008.12.001

\title{
THIRTY-YEAR CHANGES (1970 TO 2000) IN BATHYMETRY AND SEDIMENT TEXTURE RECORDED IN THE LAGOON OF VENICE SUB-BASINS, ITALY
}

\author{
Emanuela Molinaroli $^{a^{*}}$, Stefano Guerzoni ${ }^{b}$ Alessandro Sarretta $^{b}$, Mauro Masiol ${ }^{a}$, \\ Mario Pistolato ${ }^{a}$ \\ a Università Ca' Foscari Venezia, Dipartimento di Scienze Ambientali, Dorsoduro 2137, \\ 30123 Venezia, Italy \\ ${ }^{\mathrm{b}}$ CNR- Istituto di Scienze Marine, Riva VII Martiri 1364/A, 30122 Venezia, Italy \\ * Corresponding author. Tel.: +39-041-2348583; fax +39-041-2348510. \\ E-mail address: molinaro@unive.it (Emanuela Molinaroli) \\ stefano.guerzoni@ismar.cnr.it (Stefano Guerzoni) \\ alessandro.sarretta@ismar.cnr.it (Alessandro Sarretta) \\ masiol@unive.it (Mauro Masiol) \\ pist@unive.it (Mario Pisolato)
}

\begin{abstract}
A detailed comparison was made of two bathymetric charts of the Lagoon of Venice (LV) from 1970 and 2000, in tandem with a comparison of sediment grain size data. Analysis of the data revealed marked changes in both morphology and sedimentation, with more than $50 \%$ of the $400 \mathrm{~km}^{2}$ assessed in this study $15-20 \mathrm{~cm}$ shallower in 1970 than in 2000. The four sub-basins into which the LV is subdivided saw different patterns of change.

The Northern basin A was identified as "pristine", i.e. still in quasi-natural condition, with slight clay enrichment and a small degree of deepening $(4-5 \mathrm{~cm})$, essentially due to sea level rise (SLR).

The bathymetry and sedimentology of the northern-central sub-basin B (identified as
\end{abstract}


"urban") and the southern-central basin C (identified as "open”) were affected by infill activities and excavation of industrial navigation channels in the 1970s, causing the loss of $\sim 60 \mathrm{~km}^{2}$ of mudflats, and creating an "open" lagoon.

The southernmost basin D (identified as "exploited-subsiding") of the LV was found to be relatively unchanged and still in semi-natural condition.

Comparison of sediment types showed depletion of fine-grained fractions $(<22 \mu \mathrm{m})$ in all sub-basins except the northernmost one. Consequent enrichment in sand (> $63 \mu \mathrm{m}$ ) was recorded, except in the southern-central sub-basin $\mathrm{C}$ where medium and coarse sand fractions declined.

The results suggest that climate-related SLR accounts for a small fraction of bathymetric change, whilst variations in hydrodynamics (currents and wind patterns) and sediment supply are likely causal factors for the different evolution of the four subbasins.

Definition of the attributes of each sub-basin provided data that was essential not only for the LV but also for predicting the fate of transitional environments facing both anthropic (fishing, navigation, land use changes) as well natural (SLR, eustatism) forcing factors.

Keywords: bathymetry; grain-size; short-term changes; intertidal flats; transitional environments; Lagoon of Venice. 


\section{Introduction}

Knowledge of the spatial and temporal distribution of sedimentation, including processes of deposition, transport, and erosion, is fundamental for making sound decisions on a wide variety of management issues in estuaries and transitional basins (Apitz et al., 2007). Sedimentation changes bathymetry and therefore habitat extent and distribution. Predicting natural and anthropogenic changes to ecosystems and designing successful restoration projects require knowledge of deposition and erosion patterns (Jaffe et al., 2007).

Forcing factors like sea level rise (Ciavola et al., 2002), hydrodynamics and flooding affect coastal sites, leading to disappearance of salt-marshes (Bellucci et al., 2007) and intertidal flats and various negative effects (Sfriso et al., 2005). In addition, the Lagoon of Venice (LV) has undergone major physical changes following various engineering works during the last few centuries which have affected the natural evolution of the lagoon and the coastline (Serandrei-Barbero et al., 2006).

This study focuses on bathymetry and textural properties of subtidal flat sediments in the LV as revealed in sampling campaigns performed in 1970 and 2000. The difference between data from the two campaigns delineates morphological variations in the shallow lagoon beds over the thirty-year time scale and related changes in grain size distribution resulting from both natural and anthropogenic causes. Textural data generated by the same surveys were processed by identical procedures in order to ensure meaningful comparison.

With more than one inlet, the LV can be considered a "systems of lagoons" rather than a single lagoon (Tagliapietra and Ghirardini, 2006) and thus we have tried to show how different parts of the lagoon respond to the same forcing factors. 
The characteristics of each sub-basin are thus essential not only for specific and local purposes but also in a broader sense, in order to increase our general understanding of how sedimentological characteristics affect the responses of transitional environments to forcing factors, and thus provide essential data for environmental decision-making and future management of the LV.

\section{Background}

The LV is a large, shallow coastal lagoon (area: $550 \mathrm{~km}^{2}$ ) connected to the northern Adriatic Sea (North-eastern Italy Fig.1) by three tidal inlets (Lido, Malamocco and Chioggia). The LV is a complex of intertidal marshes, intertidal mudflats, submerged mudflats and navigation channels. Water exchange in the LV is governed by a microtidal regime with a mean range of $0.40 \mathrm{~m}$ during neap tides and about $0.80 \mathrm{~m}$ during spring tides.

Between the $15^{\text {th }}$ and $19^{\text {th }}$ centuries, the diversion of tributaries and major engineering works affected the natural evolution of the lagoon and the nearby coastline.

In addition, the construction of breakwaters at the lagoon inlets during the period 1808-1930 and increased dredging of lagoon channels for navigation purposes (in 1926 and 1970) have had a significant impact on the lagoon's morphology.

The most important tributaries flow into the northern basin, which on average receives more than two-thirds of the total freshwater discharge of $\sim 35 \mathrm{~m}^{3} \mathrm{~s}^{-1}$ (Collavini et al., 2005; Zuliani et al., 2005). The associated annual sediment input was calculated at $33 \times 10^{3}$ tons $\mathrm{yr}^{-1}$ for the years $1999-2000$. 
The area of salt marshes in the lagoon has fallen from about $120 \mathrm{~km}^{2}$ at the beginning of the century to about $40 \mathrm{~km}^{2}$ today, due to processes such as reclamation, erosion, pollution, and natural and human-induced subsidence (Favero, 1992; Scarton et al., 2000; Bonometto, 2005). By 1968 more than 50\% of the natural lagoon had been reclaimed $\left(160 \mathrm{~km}^{2}\right)$ or cordoned off for business-related purposes such as construction of an industrial estate and fish-farming

Groundwater pumping and consequent land subsidence began with the first industrial installations in the 1930s, and peaked between 1950 and 1970 (4-6 $\left.\mathrm{mm} \mathrm{yr}^{-1}\right)$. A recent land survey (Brambati et al., 2003) showed that subsidence has now ceased in the central part of the lagoon, but is still occurring in the northern and southern areas and surrounding land.

Between $1500 \mathrm{AD}$ and the present the average sedimentation rate has been calculated to be $0.5 \mathrm{~mm} \mathrm{yr}^{1}$. (Serandrei-Barbero et al., 2006).

Many studies have been published in recent years dealing with various aspects of the LV (Marcomini, 2005; Franco et al., 2007; Zonta et al., 2007). Most of these studies lack a detailed description of the spatial distribution and transport mechanisms of the sediments affected by changes in bathymetry, although the general textural trends in the LV are well-known (Basu and Molinaroli,1994; Albani and Serandrei-Barbero, 2001; Molinaroli et al.,2007). For example, despite the importance of accretional and erosional trends in estimating particle size/transport processes in lagoonal basins, no references or estimates for the $\mathrm{LV}$ ecosystem are available in the literature on bathymetry and grain-size.

\subsection{The LV sub-basins}


Few past studies have proposed an analysis based on the partitioning of the LV. Based on bathymetry, currents (Nyffeler ,1976), hydrodynamic models (Umgiesser, 2000; Solidoro et al., 2004, Umgiesser, 2004a) and the recent work of Tagliapietra and Ghirardini (2006), in this study the boundaries of the lagoonal basins were accurately defined by GIS-based techniques. For the first time we propose to separately analyse data from the four sub-basins. From north to south, these are (see Fig. 1): Treporti (A), Lido (B), Malamocco (C) and Chioggia (D). Table 1 shows the relevant data for each part. At $121 \mathrm{~km}^{2}$, Malamocco is the most extensive sub-basin and Lido, which includes the City of Venice, is the smallest. Treporti, the northernmost one, is the shallowest (average water depth $\sim 1 \mathrm{~m}$ ) with the highest relative proportion of salt marshes (more than $14 \%, \sim 13 \mathrm{~km}^{2}$ ). The deepest sub-basin is Lido (average water depth $\sim 2 \mathrm{~m}$ ) which is thus characterised by few salt marshes $(<4 \%)$.

\section{Materials and methods}

\subsection{Bathymetry: data processing and analysis}

Bathymetric data for the LV were provided by the "Servizio Informativo del Magistrato alle Acque di Venezia" (Venice Water Authority Information System = MAV). The data were drawn from two survey campaigns, one conducted in the 1970s and the other in the 2000s. Depth is expressed with reference to mean sea level as measured in 1942 in Genova.

The "1970 dataset" ( 179000 points) was collected in the period 1968-1971. It was extracted from the "Carta Idrografica della Laguna di Venezia" (Hydrographic map of the Lagoon of Venice), plotted by the "Ufficio Idrografico del Magistrato alle Acque di 
Venezia” (Venice Water Authority Hydrographic Service). Bathymetric points were gathered by theodolite on land and stadia rod on shallow flats.

The "2000 dataset" ( 166000 points) was collected from the end of 1999 to June 2002, further data being collected in spring 2003. A "Multibeam" bathymetric acquisition system was used for the main channels (depth $>5 \mathrm{~m}$ ) and the three inlets (Lido, Malamocco, Chioggia). For shallow waters and secondary channels (depth $<5 \mathrm{~m}$ ), a single-beam echo-sounder was used. Where depth was very small (areas near salt marshes and mudflats), data was collected by the traditional topographic method (stadia rods with GPS). The distribution of natural and artificial salt marshes was surveyed by stereo aerial photography.

In order to minimize smoothness effects in areas with greater slopes (especially between channels and salt marshes), the bathymetric data from both datasets were subdivided into three sub-datasets before interpolation, corresponding to the main morphological units of the lagoon: channels, shallow flats and marshes. The three sub-datasets were separately interpolated with the IDW (Inverse Distance Weighted) algorithm (power: 2, n. of points: 5) to obtain three raster files with pixels of $10 \times 10$ metres resolution. These raster files were then merged to obtain a single raster for the whole lagoon for each period. The comparison was performed by a Map Algebra operation using the ArcGIS "Raster Calculator" tool. The bathymetric values of the 1970 grid were subtracted from the 2000 values, generating a raster map of depth differences with the same resolution as the input maps. The final map [(2000 bathymetry) - (1970 bathymetry) - (subsidence between 1970 and 2000)] enabled a detailed assessment of the morphological changes occurring during the last 30 years. The data were organized, processed and presented 
using ESRI ArcGIS 8.3 software. The projection system is the Gauss-Boaga Eastern zone.

\subsection{Sampling and grain size analysis}

The surficial sediment samples processed for this study are from two different sampling campaigns: the first was performed in the 1970s and the second in the 2000s.

The samples from the first campaign were collected between 1976 and 1978 by the Sezione Geo-Mineralogica of Venice Ca' Foscari University and are hereafter referred to as "GM70". One-hundred and fifty sediment samples $(\sim 10 \mathrm{~cm}$ depth $)$ were collected by PVC pipe from beds at depths of between 0.1 and $2.4 \mathrm{~m}$. The particle size distributions of the majority of these samples were extracted from published and unpublished reports (Hieke Merlin et al., 1979; Vianello, 1981; Menegazzo Vitturi and Molinaroli, 1984; Molinaroli and Rampazzo, 1986; Menegazzo Vitturi et. al., 1987; 1989; Pistolato, 2004; Masiol, 2005). To complete the dataset, 13 samples from the 1970 dataset - not previously considered - were also analysed for the present study, resulting in a total of 162 samples.

The second set of samples was collected in the year 2002 by the Institute of Marine Sciences of Venice, hereafter referred to as "UI00". One hundred and forty sediment samples were collected by PVC pipe ( $~ 8 \mathrm{~cm}$ depth) from beds at depths of between 0.2 and $2.2 \mathrm{~m}$.

Samples were taken from the whole lagoon, with the exception of fish farms, reclaimed areas, a small area just inside the Lido inlet, and the landward area behind the reclaimed areas. The area actually studied thus covered $\sim 350 \mathrm{~km}^{2}$, compared to the total lagoon area of $\sim 400 \mathrm{~km}^{2}$. 
Sample treatment methods and analytical procedures used for the two sampling campaigns were essentially identical. Sediment samples were pre-treated with $\mathrm{H}_{2} \mathrm{O}_{2}$ ( $20 \%$ vol.) to eliminate organic material, washed with bi-distilled water to eliminate chlorides, then oven-dried at $40^{\circ} \mathrm{C}$ for 12 hours. Than samples were sieved for the $<1$ $\mathrm{mm}$ fraction in order to eliminate clam shells and fragments.

Grain size analyses of the sediments were performed by dry sieving and a SediGraph 5000D (Micromeritics ${ }^{\mathrm{TM}}$ ) particle analyser for the sand and mud fractions, respectively. The mud samples were pre-treated with $6 \%$ o Na-hexametaphosphate solution for 24 hours and then sonicated for 15 min before analysis.

The results yielded the two grain-size datasets GM70 and UI00 (Fig.1). Sediments were classified using the ternary diagrams proposed for the textural classification of gravelfree sediments by Flemming (2000) (Note: data files are in the additional listings, available on request from the authors).

\section{Results}

\subsection{Bathymetry and sedimentation changes}

The LV changed markedly between 1970 and 2000. The resultant changes are depicted in the bathymetry and sedimentation grids, based on more than 170,000 depth soundings (Figs. 2 and 3).

Colour-shaded bathymetric maps for the two periods in Fig. 2 allow comparisons, and Fig. 3 shows calculated bathymetric differences (in metres) between 1970 and 2000. Other factors contributing to bathymetric change such as subsidence, dredging or vertical datum differences must be accounted for prior to applying the methodology 
used here. For instance, subsidence data were taken from Brambati et al., 2003 (see inset in Fig. 3) and these values were subtracted from the differences at each location. In Fig. 3, a decrease in depth between the two time periods (resulting in a shallower lagoon) indicates sediment deposition (brown colours). An increase in depth (resulting in a deeper lagoon) indicates sediment erosion (light blue and dark blue represent moderate and strong erosion, respectively).

In 1970, the LV had a complex morphology with a large number of minor channels which were less pronounced or inexistent by 2000 , whereas the main channels were partially silted up or unchanged: the average depth of the channels was $\sim 6.0 \mathrm{~m}$ in 1970 , and $5.5 \mathrm{~m}$ in 2000 . The mean depth of shallow flats was $0.85 \mathrm{~m}$ in 1970 and $1.05 \mathrm{~m}$ in 2000. An overall increase in lagoon depth is therefore evident, especially in the southernmost part where the difference in average depth was $\sim 0.30 \mathrm{~m}$ (from $-0.90 \mathrm{~m}$ in 1970 to $-120 \mathrm{~m}$ in 2000 ) compared to $\sim 0.10 \mathrm{~m}$ in the northern basin (from $-0.75 \mathrm{~m}$ to $0.85 \mathrm{~m}$ ). As a consequence, the $-1.20 \mathrm{~m}$ contour was displaced towards the shores of the lagoon, and the area deeper than $1.20 \mathrm{~m}$ increased from $\sim 90 \mathrm{~km}^{2}$ in 1970 to more than $\sim 150 \mathrm{~km}^{2}$ in 2000 (Fig. 2).

More than $50 \%$ of the $\sim 400 \mathrm{~km}^{2}$ assessed in this study was shallower in 1970 than in 2000 (Fig. 3). Erosion was moderate (i.e., with differences in depth of between $0.10 \mathrm{~m}$ and $0.50 \mathrm{~m}$ over 30 years, or 3-15 $\left.\mathrm{mm} \mathrm{yr}^{-1}\right)$ for $\sim 140 \mathrm{~km}^{2}$, and strong $(>0.50 \mathrm{~m})$ for $70 \mathrm{~km}^{2}$. The lagoon bed was most severely eroded near the seaward inlets. In contrast, the northern shallows and lagoon margins were depositional, as were many of the channels throughout the lagoon, which were silted up to varying degrees due to erosion of surrounding shallow flats. Some channels, however, are deeper today than 30 years ago because of continuous dredging for navigation purposes. Only one-quarter of the 
lagoon depth remained constant over the 30 year period. Thus, overall between 1970 and 2000, the LV lost sediment, continuing a tendency already observed in the previous $\sim 40$ years (Pillon et al., 2003). A net volume of $28 \pm 3 * 10^{6} \mathrm{~m}^{3}$ of sediment was therefore removed, at an average rate of $0.9 \pm 0.1 * 10^{6} \mathrm{~m}^{3} \mathrm{yr}^{-1}$, from the LV (Sarretta, 2007).

\subsubsection{Distribution of elevations}

To further examine changes in morphology between 1970 and 2000, the distribution of surface areas as a function of elevation was calculated for the whole lagoon (Fig. 4). A clear shift in the frequency curves between 1970 and 2000 is evident, the most frequent (peak) elevation having changed from a value of $\sim-0.80 \mathrm{~m}$ in 1970 to $\sim-1.00 \mathrm{~m}$ in 2000. Indeed the frequency peaks for both periods differ completely from the value of $0.50 \mathrm{~m}$ found by Fagherazzi et al. (2006) who examined bathymetric data collected almost one century ago. Those authors showed that shallow tidal basins (such as the Lagoon of Venice) are characterised by extensive tidal flats and salt-marshes that lie within specific ranges of elevations, and intermediate elevations $(+/-0.25 \mathrm{~m})$ are less frequent due to their inherent instability. With high deposition rates - such as those of 1900 - the most frequent tidal flat elevation was around -0.50 , which tended to shift towards lower elevations where sediment availability was reduced (Fagherazzi et al., 2006; Defina et al., 2007).

The shift from a value of $-0.50 \mathrm{~m}$ at the beginning of the $20^{\text {th }}$ century to $-0.80 \mathrm{~m}$ in 1970 reflects reduced sediment input due to reclamation activities and damming of rivers in the 1930s. The additional shift towards $-1.00 \mathrm{~m}$ by 2000 coincides with further sediment loss due to higher energy levels (currents) resulting from the excavation of the 
Malamocco-Marghera channel, with input from rivers remaining low.

The possible role of the $4-5 \mathrm{~cm}$ relative sea level rise during the last 30 years

(Butterfield, 2004) in the deepening of tidal flats was also examined. Defina et al.

(2007) recently demonstrated that an increase in water depth due to sea level rise is partly offset by a decrease in erosion, and the result is an increase in water depth over tidal flats of less than the sea level rise. Therefore the recorded deepening of tidal flats in the LV (by approximately $20 \mathrm{~cm}$ ) is mainly due to a decrease in sediment supply, together with a loss of sediments due to harvesting of Manila clams since the early 1990s (Sfriso et al., 2005), rather than to relative sea level rise, which merely speeded up this evolutionary trend.

Comparison of the two curves in Fig. 4 highlights an increase in the frequency of depths of $<-1.2 \mathrm{~m}$ in 2000, corresponding to an increase of $60 \mathrm{~km}^{2}$ in areas deeper than $<-1.2$ m.

\subsubsection{Differences in shallow flats in the four LV sub-basins}

Focusing on the shallow lagoonal flats $\left(\sim 300 \mathrm{~km}^{2}\right)$, the specific features of each subbasin were identified. Fig. 5 shows the comparative elevation profiles for each of the four basins and Table 2 gives an estimate of the magnitude of erosion and deposition derived from a comparison of the depth differences (Fig. 3) in each sub-basin.

In Basin A, the morphology is very similar for the two periods considered. In this basin, $\sim 50 \%$ of the area can be considered stable $( \pm 0.1 \mathrm{~m})$; there is a general shift of $10 \mathrm{~cm}$ (from $\sim-0.6$ to $\sim-0.7 \mathrm{~m}$ ) for the most frequent elevation.

In Basin B, beds are mainly stable or rising to the north of Venice city, whereas south of Venice moderate erosion is seen. The profiles indicate a general drop of $0.20 \mathrm{~m}$ (from 
-0.9 to $\sim-1.1 \mathrm{~m}$ ) for the most frequent elevations, accompanied by net losses of tidal flats (between -0.30 and $-0.80 \mathrm{~m}$ ).

Basin $\mathrm{C}$ saw the greatest changes in morphology. Approximately $80 \%$ of this sub-basin experienced either strong (40\%) or moderate (40\%) erosion. Dark blue colours (Fig. 3) indicate a lowering of more than $0.50 \mathrm{~m}$, with the biggest drops (up to $1.2 \mathrm{~m}$ ), occurring near the Malamocco seaward inlet and in the Malamocco-Marghera shipping channel (used by oil tankers). Excavation of navigation channels through the seaward inlets and across the lagoon, carried out mainly in the 1960 s, significantly altered water circulation within the lagoon (MAV-CVN, 1999). Low intertidal mudflats and subtidal flats at depths of between $0.40 \mathrm{~m}$ and $1.20 \mathrm{~m}$ water have been substantially eroded, producing deeper subtidal flats and open lagoon conditions with depths ranging from 1.30 to more than 2 metres. The highest frequency depth in this sub-basin was around $-1.80 \mathrm{~m}$ in 2000 compared to $-0.80 \mathrm{~m}$ in 1970.

In basin D a similar shift is also apparent, albeit less pronounced, with a lowering of $0.30 \mathrm{~m}$ in the most frequent elevation (from $\sim-0.70$ to $\sim-1.00 \mathrm{~m}$ ), and an increase in frequency of elevations between -1.20 and $-2.00 \mathrm{~m}$. In the southernmost part of this basin, some stable and rising beds are evident, probably due to the disintegration of the salt marshes. Erosion has mainly affected areas near the Chioggia seaward inlet. Differences between 1970 and 2000 in the central-southern parts of the LV are probably due to the fully-developed wavefield conditions which obtain over most of the lagoon south of Venice (Defina et al., 2007). In this part of the LV tidal currents and bed shear stress due to wind waves and fetch length increased between 1970 and 2000, mainly in the $\mathrm{B}$ and $\mathrm{C}$ sub-basins and are the causal explanation of changes in bathymetry (Amos et al., 2004; Umgiesser et al, 2004b; Molinaroli et al., 2007). 


\subsection{Sediment characteristics and temporal variability}

The surficial sediments of the lagoon consist predominantly of clayey silts in both datasets (mean mud content was $75 \%$ for GM70 and $68 \%$ for UI00, dry weight). In both datasets the silt fraction dominates over other fractions, but with a general tendency to decrease between 1970 and 2000, with the exception of basin C (Table 3). In all subbasins, GM70 samples have a lower sand content than the UI00 samples. The GM70 and UI00 samples have similar clay content, except for sub-basins A and D, where slight differences between the two datasets are observed (Table 3). The distribution of values around the mean indicates a wide range of particle sizes and variable physical energy in the system. The lagoon varies from relatively high energy on the seaward side, influenced by tidal flow through the three inlets connecting the lagoon to the Adriatic, to quiescent conditions on the landward side (Umgiesser et al., 2004b; Molinaroli et al., 2007).

The average frequency curve of the mud samples a pronounced peak for coarser silt at $\sim 22 \mu \mathrm{m}$ in sub-basins B, C, and D, less-well defined in sub-basin A (Fig. 6) in both datasets. A slightly flat tail on the finer silt and clay side in all sub-basins was observed for the two datasets. An important characteristic is that both populations are characterised by a deficiency of particles at $\sim 8 \mu \mathrm{m}$, which means that they are composed of two major sub-populations, one greater and one smaller than this size. The $8 \mu \mathrm{m}$ size fraction marks the transition between the sortable coarser-grained and the aggregated finer-grained sub-populations (McCave et al., 1995). A similar observation was made by Chang et al. (2006) who observed an even more pronounced lack of particles at $\sim 8 \mu \mathrm{m}$ in a back-barrier tidal basin in the Wadden Sea. An analogous trend was also detected by De Falco et al. (2004) in the Cabras lagoon from Sardinia in the 
Western Mediterranean. The $<8 \mu \mathrm{m}$ fraction is known as the non-sortable silt fraction (McCave et al., 1995), consisting of both single particles and an aggregated or flocculated fraction, whereas the 8-63 $\mu \mathrm{m}$ fraction may be considered as nonaggregated silt particles.

The grain-size trends of the two datasets are represented by ternary diagrams on the basis of sand/silt/clay ratios Flemming (2000), the location of data points within the diagram reflecting specific hydrodynamic energy conditions (Fig. 7). Sediment composition is described by a diagonal band that gradually expands towards the siltclay axis. While there are some differences between the two time periods, there is a general tendency for the three ratios to plot within a band, reflecting an intermediate energy gradient (Flemming, 2000), commonly found in intertidal sediments that are consistently silt-dominated. However, in sub-basin A the textural gradient shows a shift towards higher silt/clay content (slightly clayey silt and clayey silt) between 1970 and 2000, indicating a general decrease in energy in this sub-basin. In sub-basin B, most of the sediments have become richer in sand (very silty sandy mud, silty sandy mud and very silty sand), while those of sub-basins C and D have become richer in slightly silty sands, silty sands and very silty sands.

The major difference between the two datasets is thus their sand content. The higher sand content in UI00 samples is probably related to changes in hydrodynamic energy. The results confirm a previous study (Molinaroli et al., 2007) in which LV sediments sampled in the period 1997-98 were found to be more similar to back-barrier tidal flats (Danish Wadden Sea) and bays (Minas Basin, Bay of Fundy, Canada) than lagoon sediments (Mugu Lagoon, California). 
On the other hand, the two datasets also highlight the presence of finer materials in the northern basin (mean mud content $\sim 90 \%$ in both datasets), reflecting a less energetic hydrodynamic system, with little change over the past thirty years. In order to isolate aggregated muds from sortable silts in the frequency distribution curves of mud fractions in the four sub-basins, ternary diagrams were drawn up based on the grain-size fractions $>63 \mu \mathrm{m} / 63-8 \mu \mathrm{m} /<8 \mu \mathrm{m}$ (Fig. 7). The ternary plots show that several samples are mainly composed of aggregate mud ( $<8 \mu \mathrm{m}$ fraction), particularly in sub-basin A. The flocs and aggregates behave like hydraulically coarser sediment grains and are more common in samples from GM70.

The results, highlighted by the Flemming classification, can be represented spatially by the distribution of the sand fraction in the lagoon (Fig. 8). A clear increase in sand content from GM70 to UI00 can be seen throughout sub-basins C and D, especially towards the landward side. Very high sand content is also evident in UI00 samples from sub-basin B and around the city of Venice. Sub-basin A does not show significant variations.

Although the ternary diagrams and the grain-size distribution maps reveal a clear pattern of change, this in itself does not explain the causes of the change. Molinaroli et al. (2007) reported good correlations of two grain size fractions, i.e. very fine sand (63$105 \mu \mathrm{m})$ and coarse silt $(4-31 \mu \mathrm{m})$, with two hydrodynamic parameters, namely mean square velocity and residence time of tidal waters respectively. A more detailed examination of the sandy and silty fractions in the two sample sets was thus performed in order to shed more light on the hydrodynamic significance of the grain size differences. In the lagoon as a whole, the $>420 \mu \mathrm{m}$ and $420-250 \mu \mathrm{m}$ fractions contribute very little to the total sand fraction, and have similar values in the two 
datasets. From GM70 to UI00, fine sand (250-105 $\mu \mathrm{m})$ and very fine sand (105-63 $\mu \mathrm{m})$ increased by $30 \%$ and $50 \%$ respectively. The former rose in all four sub-basins except $\mathrm{C}$ (Table 4), while the latter rose in all sub-basins. The presence of fine and very fine sand as the main textural fractions in the central and southern part of the lagoon was previously reported by Albani and Serandrei-Barbero (2001) for samples collected in 1983.

Coarse silt (63-22 $\mu \mathrm{m})$ decreased from GM70 to UI00 in sub-basins A and B, but increased in sub-basin C. Fine silt $(22-2 \mu \mathrm{m})$ decreased from GM70 to UI00 in all subbasins.

\section{Discussion}

Changes in bathymetry and surficial sediment grain-size between 1970 and 2000 provide data for a clear and unambiguous zonation of the LV. These show distinct altimetric changes over time defined in the four lagoon sub-zones, as well as changes in textural characteristics, which are correlated with erosion or deposition.

We have already seen that a small part of the altimetric change $(\mathrm{a} f \mathrm{fw} \mathrm{cm})$ is accounted by the mean sea level rise ( $1.3 \mathrm{~mm} \mathrm{yr}^{-1}$, Butterfield, 2004), whilst factors such as hydrodynamics (fetch and wind patterns) and clam harvesting - which do not affect all parts of the lagoon to the same degree - are responsible for the different patterns of change in the four sub-basins (Umgiesser et al., 2000; Umgiesser et al., 2004a; Sfriso et al., 2005).

The changes in grain size distribution in the LV from 1970 to 2000 reflect both natural and anthropogenic changes. The bulk of the fine silt and clay fractions $(<22 \mu \mathrm{m})$ may 
represent sediment carried by fluvial system. With the reduction of sediment supply by rivers (due to dam-building inland), only fine sediment was added to the lagoon during these 3 decades. Zonta at al. (2005) reported that material transported by one of the biggest rivers discharging into the northern lagoon is particularly fine, with $80 \%$ finer than $<20 \mu \mathrm{m}$, the mode being about $7 \mu \mathrm{m}$. The same authors report that the total amount of material transported fluvially from the catchment area is $\sim 32 * 10^{3}$ tons $\mathrm{yr}^{-1}$. Of this, 14 tons $\mathrm{yr}^{-1}$ enters sub-basin A, 8 tons $\mathrm{yr}^{-1}$ enters sub-basin $\mathrm{B}, 4$ tons $\mathrm{yr}^{-1}$ subbasin $\mathrm{C}$, and 6 tons $\mathrm{yr}^{-1}$ sub-basin $\mathrm{D}$. Those amounts were drastically reduced in the 30 year period considered here, thus creating the conditions for erosion, in which salt marshes deteriorate and shrink and then tidal flats deepen.

Very fine sand and coarser silt may be related to the distribution of unconsolidated sediments deposited along the edges of the three seaward inlets, while coarser sand on the landward side of the lagoon is perhaps associated with ancient fluvial deposits and erosion of both natural and artificially developed salt marshes (Day et al., 1998). The northern lagoon had the most resistant tidal flats, due to the stabilizing effect of cyanobacteria, microphytobentos and seagrass beds. In contrast, bare shallow beds were the least resistant (Amos et al., 2004). The reduction in size or disappearance of seagrass beds in the last three decades, together with clam fishing, have led to destabilisation of shallow flats, mainly in sub-basins B and C (Sfriso et al., 2005; Molinaroli et al., 2007).

Taking all the data into account, it is therefore possible to characterise the main "attributes" of each of the four sub-areas as follows (Tab. 5):

\subsection{Classification of sub-areas}


The northern basin (Treporti, A) is the most "pristine". It is characterised by natural conditions, and is a typical transitional area. It still receives riverine particulate input (fine-grained sediment) and is not seriously affected by morphological variation. It contains more than $30 \%$ of the lagoon's salt marshes. Grain-size composition shows a $7 \%$ loss of silt, compensated by a $5 \%$ gain in clay (largely from riverine deposition). Fifty percent of the area is stable, erosion equals deposition $(\mathrm{E} / \mathrm{D} \cong 1)$ and the slight bathymetric deepening since 1970 is due solely to sea level rise. The ternary plot of sediment samples from stable and moderately eroded areas (Fig. 9a) in most cases shows a grain-size shift between 1970 and 2000 from very silty slightly sandy mud and clayey silt to silty slightly sandy mud, indicating a small reduction in hydrodynamic energy affecting the bed.

The northern-central basin (Lido, B) is the "urban lagoon", with the cities of MestreMarghera and Venice, the Murano glass district, the Lido coastal area (tourism) and Tessera airport all looking on to it. There is some (fine) sediment input from the catchment area. This sub-basin contains only $5 \%$ of the lagoon's marshes, which suffered little or no loss in the 30 year period. This sub-basin experienced loss of the $<22 \mu \mathrm{m}(-9 \%)$ and 63-22 $\mu \mathrm{m}(-3 \%)$ grain size fractions and the highest relative increase in sand $(+12 \%)$; the latter is linked to the mainly moderate erosion of this basin (affecting $\sim 50 \%$ of the area, $32 \mathrm{~km}^{2}$ of $66 \mathrm{~km}^{2}$ ). The eroded area is three times larger

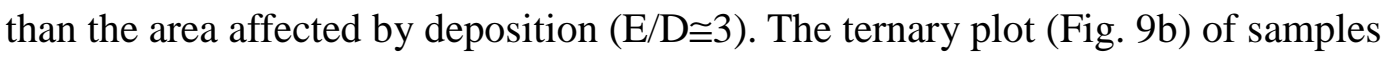
collected in moderately eroded areas shows a grain-size shift between 1970 and 2000 from slightly clayey silt and clayey silt to very silty slightly sandy mud and silty slightly sandy mud. In addition very silty sand, silty sand and slightly silty sand only occur in the 2000 dataset, indicating increased hydrodynamic energy in recent years. 
The southern-central basin (Malamocco, C) is of the "open lagoon" type, marine in character, subject to high energy, with little sediment input. This basin includes $25 \%$ of the lagoon's salt-marshes $\left(11 \mathrm{~km}^{2}\right)$, of which more than $3 \mathrm{~km}^{2}$ were lost between 1970 and 2000. This sub-basin underwent the most dramatic changes in the period, mainly due to excavation of the Malamocco-Marghera channel. It may be considered a prototype for the future fate of the entire lagoon (Fagherazzi et al., 2006). It experienced loss of all grain-size fractions except fine sands $(105-63 \mu \mathrm{m},+8 \%)$, including significant and atypical loss $(-7 \%)$ of coarse sand $(>105 \mu \mathrm{m})$. This was probably the result of lagoon bed disturbance by clam fishing and strong currents linked to the Malamocco-Marghera navigation channel. Indeed, recent studies have shown that the Malamocco inlet is the most important point of sediment loss from the LV to the Adriatic Sea (Zaggia et al., in preparation). From 1970 to 2000, 80\% of basin C was affected by erosion ( $40 \%$ high and 40 moderate), making it the most unstable of the lagoon in sedimentary terms. The eroded area was five times larger than the one affected by deposition $(\mathrm{E} / \mathrm{D} \cong 5)$. As a further demonstration of the changes in hydrodynamic energy, the ternary plot (Fig. 9c) of the samples collected in strongly eroded areas shows the disappearance of the silty slightly sandy mud present in the 1970 samples in favour of very silty sandy mud and silty sandy mud in the 2000 samples.

The southernmost basin (Chioggia, D) is of the "exploited-subsiding lagoon" type. It is still in a quasi-natural condition, but exploitation for aquaculture and fishing and high subsidence has influenced its morphology: $1 \mathrm{~km}^{2}$ of salt-marshes out of $13 \mathrm{~km}^{2}$ was lost between 1970 and 2000. Its sediments were depleted in both silt and clay (-10\%) and consequently enriched in sand. Forty percent was moderately eroded, but there was also 
some deposition (25\%) due to disintegration of salt-marshes, and more than $30 \%$ of the

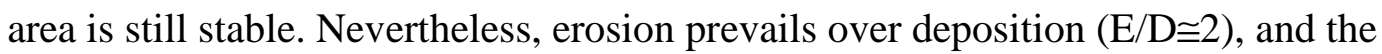
grain-size patterns in eroded and stable/depositional areas are similar. It is thus possible that the coarser sand fraction $(>105 \mu \mathrm{m})$ is subject to internal re-sedimentation in this sub-basin, whereas in sub-basin $\mathrm{C}$ it is probably lost to the sea.

\section{Conclusions}

The main results of a detailed GIS-based comparison of bathymetry, grain-size and morphology from data collected in 1970 and 2000 are the following:

1) The LV should not be considered as a single lagoon, but rather as subdivided into four sub-basins: changes occurring during the 30-year period are specific to each sub-basin due to variations in sediment input, erosion versus deposition, hydrodynamic energy and land-use.

2) There has been a general reduction in the frequency of depths of $-0.60 /-0.80 \mathrm{~m}$, combined with a general increase in frequency of elevations of $-1.00 /-1.20 \mathrm{~m}$ in subbasins $\mathrm{B}$ and $\mathrm{D}$, and up to $-1.80 \mathrm{~m}$ in sub-basin $\mathrm{C}$. This shift has caused a "smoothing" of the lagoonal morphology with a concomitant transition from intertidal flats to subtidal flats $\left(\sim 30 \mathrm{~km}^{2}\right)$ and from subtidal flats to open lagoon conditions $\left(\sim 60 \mathrm{~km}^{2}\right)$.

3) The recorded deepening of tidal flats (by approximately $20 \mathrm{~cm}$ ) is to be ascribed more to decreased sediment supply, disappearance of seagrass and clam fishing than to the relative sea level rise of $\sim 5 \mathrm{~cm}$. Changes in the bathymetry and grain size distribution of the central and southern basins of the LV are probably due to changes 
in tidal currents, bed shear stress from wind waves and fetch length.

4) More than $50 \%$ of the lagoon experienced erosion in the 30 -year period, only $25 \%$ remaining stable. Comparison of sediment types shows that all basins experienced depletion of the fine-grained sediments $(<22 \mu \mathrm{m})$, and a shift in sedimentary facies from lower to higher energy patterns.

5) On the basis of detailed grain-size analyses, the paucity of $\sim 8 \mu \mathrm{m}$ particles in the frequency distribution roughly separates the population into two classes: sortable silts and aggregated fine silty clays;

6) Definition of the attributes characteristic of each sub-basin can provide essential data for environmental decision-making and the future management of the LV.

\section{Acknowledgements}

We thank the Water Management Authority of Venice for providing data and supporting A.S. with a fellowship. Mr. George Metcalf revised the English text. We thank JeanDaniel Stanley, an anonymous reviewer and the Editor John T. Wells for their careful reviews and comments. 


\section{References}

Apitz, S.E., Barbanti, A., Bernstein, A.G., Bocci, M., Delaney, E., Montobbio, L., 2007. The assessment of sediment screening risk in Venice lagoon and other coastal areas using international sediment quality guidelines. J. Soil Sed. 7, 326-341.

Albani, A.D., Serandrei Barbero, R., 2001. The distribution of surface sediments in the lagoon of Venice (Italy) in the 1980s. Atti Istituto Veneto SS. LL. AA. 159, 363-378.

Amos, C.L., Bergamasco, A., Umgiesser, G., Cappucci, S., Cloutiere, D., DeNat, L.,

Flindt, M., Bonardi, M., Cristante, S., 2004. The stability of tidal flats in Venice Lagoon - the results of in-situ measurements using two benthic, annular flumes. J. Marine Syst. 51 211-241.

Basu, A., Molinaroli, E., 1994. Toxic metals in Venice lagoon sediments: model, observation, and possible removal. Environ. Geol. 24, 203-216.

Bellucci, L.G., Frignani, M., Cochran, J.K., Albertazzi, S., Zaggia, L., Cecconi G., Hopkins, H., 2007. ${ }^{210} \mathrm{~Pb}$ and ${ }^{137} \mathrm{Cs}$ as chronometers for salt marsh accretion in the Venice Lagoon and links to flooding frequency and climate change. J. Environ. Radioactiv. 97, 85-102.

Bonometto, L., 2005. Functional characteristics of salt marshes (barene) in the Venice Lagoon and environmental restoration scenarios. In: Fletcher, C.A., Spencer, T. (Eds.), Flooding and Environmental Challenges for Venice and its Lagoon: State of Knowledge. Cambridge University Press, Cambridge UK, pp. 473-486.

Brambati, A., Carbognin, L., Quaia, T., Teatini, P., Tosi, L., 2003. The Lagoon of Venice: Geological setting, evolution and land subsidence. Episodes 26, 264-268.

Butterfield, R., 2004. On subsidence and eustacy in relation to Venice. Proceedings of a Three Day Conference on Advanced Geotechnical Engineering, pp. 1231-1242. 
Chang, T.S., Joerdel, O., Flemming, B.W., Bartholomä, A., 2006. The role of particle aggregation/disaggregation in muddy sediment dynamics and seasonal sediment turnover in a back-barrier tidal basin, East Frisian Wadden Sea, southern North Sea. Mar. Geol. 235, 49-61.

Ciavola, P., Organo, C., León Vintró, L., Mitchell, P.I., 2002. Sedimentation processes on intertidal areas of the Lagoon of Venice: identification of exceptional flood events (Acqua Alta) using radionuclides. J. Coastal Res., Special Issue, vol. 36, pp. 139-147.

Collavini, F., Bettiol, C., Zaggia, L., Zonta, R., 2005. Pollutant loads from the drainage basin to the Venice Lagoon (Italy). Env. Int. 31, 939-947.

Day, J.W., Scarton, F., Rispondo, A., Are, D., 1998. Rapid deterioration of a salt marsh in Venice Lagoon. J. Coast.Res. 14, 583-590.

De Falco, G., Magni, P., Teräsvuori, L.M.H., Matteucci, G., 2004. Sediment grain size and organic carbon distribution in the Cabras Lagoon (Sardiani, Western Mediterranean). Chemistry and Ecology 20 (Suppl.1), 367-377.

Defina, A., Carniello, A., Fagherazzi, S., D’Alpaos, L. 2007. Self-organization of shallow basins in tidal flats and salt marshes. J. Geophys. Res. 112, F03001, doi:10.1029/2006JF000550.

Fagherazzi, S., Carniello, L., D’Alpaos, L., Defina, A., 2006. Critical bifurcation of shallow microtidal landforms in tidal flats and salt marshes. PNAS 103, 8337-8341.

Favero, V., 1992. Evoluzione morfologica e trasformazioni ambientali dalla conterminazione lagunare al nostro secolo. Con terminazione lagunare: storia, ingegneria, politica e diritto nella Laguna di Venezia. Proceeding of the Conference "Convegno di studi bicentenario della con terminazione lagunare", Venice, Italy, pp. 165. 
Flemming, B.W., 2000. A revised textural classification of gravel-free muddy sediments on the basis of ternary diagrams. Cont. Shelf Res. 20, 1125-1137.

Franco, A., Torricelli, P., Elliott, M., 2007. Preface: Biodiversity and ecosystem functioning in coastal and transitional waters. Estuar. Coast. Shelf Sci. 75 (1-2), 1-3.

Hieke Merlin, O., Menegazzo Vitturi, L., Semenzato, G., 1979. Contributo alla conoscenza dei sedimenti superficiali della Laguna Veneta. Atti Istituto Veneto SS. LL. AA. $137,36-51$.

Jaffe, B.E., Smith, R.E., Foxgrover, A.C., 2007. Anthropogenic influence on sedimentation and intertidal mudflat change in San Pablo Bay, California: 18561983. Estuar. Coast. Shelf Sci. 73, 175-187.

Marcomini, A., 2005. Preface. Env. Int. Special Issue, vol. 31, pp. 921-922.

Masiol, M., 2005. Caratterizzazione sedimentologica di un'area della Laguna di Venezia. Valutazione delle variazioni granulometriche in relazione alle modificazioni batimetriche. Tesi di Laurea Specialistica, Università Ca’ Foscari di Venezia. 153 pp. M.A.V.-C.V.N. 1999. Mappatura dell'inquinamento dei fondali lagunari. Studi ed indagini, relazione finale luglio 1999. Consorzio Venezia Nuova.

McCave, I.N., Manighetti, B., Robinson, S.G., 1995. Sortable silt and fine sediment size/composition slicing: parameters for palaeocurrent speed and palaeoceanography. Paleoceanography 10, 593-610.

Menegazzo Vitturi, L., Molinaroli, E., 1984. Il ruolo della caratteristiche mineralogiche e fisiche dei sedimenti nei processi di inquinamento di un'area tipo della laguna veneta. Atti Istituto Veneto SS. LL. AA. 9, 353-367.

Menegazzo Vitturi, L., Molinaroli, E., Pistolato, M., Rampazzo, G., 1987. Geochemistry of recent sediments in the lagoon of Venice. Rend. Soc. It. Mineral. e Petrol. 42, 59- 
72.

Menegazzo Vitturi, L., Molinaroli, E., Pistolato, M., Rampazzo, G.., 1989. Sediment properties and their influence on the geochemical composition in the Lagoon of Venice. Boll. Oceanol. Teor. Appl. 7, 191-205.

Molinaroli, E., Rampazzo, G., 1986. Contributo alla conoscenza mineralogica dei sedimenti della Laguna Veneta: minerali pesanti. Atti e Mem. Acc. Patavina Sci., Lett. Arti 67, 159-176.

Molinaroli, E., Guerzoni, S., Sarretta, A., Cucco, A., Umgiesser, G., 2007. Link between hydrology and sedimentology in the Lagoon of Venice, Italy. J. Marine Syst. 68, 303317.

Nyffeler, F., 1976. Le régime hydrodynamique de la lagune de Venise: incidence sur les phénomènes de transport. Stamperia di Venezia, Venezia Italia, 88 pp.

Pillon, S., Fontolan, G., Bezzi, A., Burla, I., Tessari, U., Simeoni, U., Zamariolo, A., Tromellini, E., Gabellino, M., 2003. A GIS-based morphological evolution of the Venice Lagoon. In: Proc. VI Int. Conf. on Med. Coast. Env. MEDCOAST03, 2, pp.1269-1280.

Pistolato, M., 2004. Studio delle relazioni esistenti tra composizione granulometrica, area superficiale specifica e contenuto di metalli pesanti in campioni di sedimento della Laguna di Venezia. Tesi di Laurea Triennale, Università Ca’ Foscari di Venezia. $83 \mathrm{pp}$.

Sarretta, A., 2007. Integrazione di dati granulometrici e informazioni ambientali nella laguna di Venezia per lo studio degli habitat di fondo. Ph.D thesis, Università Ca' Foscari, Venezia. 189 pp.

Scarton, F., Day, J.W., Rismondo, A., Lecconi, G., Are, D., 2000. Effects of an intertidal 
sediment fence on sediment elevation and vegetation distribution in a Venice (Italy) lagoon salt marsh. Ecol. Eng. 16, 223-233.

Serandrei-Barbero, R., Albani, A., Donnici, D., Pizzetto, F., 2006. Past and recent sedimentation rates in the Lagoon of Venice (Northern Italy). Estuar. Coast. Shelf Sci. 69, 255-269.

Sfriso, A., Facca, C., Marcomini, A., 2005. Sedimentation rates and erosion processes in the lagoon of Venice. Env. Int., Special Issue, vol. 31, pp 983-992.

Solidoro, C., Melaku Canu, D., Cucco, A., Umgiesser, G., 2004. A partition of the Venice Lagoon based on physical properties and analysis of general circulation. J. Marine Syst. 51, 147-160.

Tagliapietra, D., Ghirardini, A.V., 2006. Notes on coastal lagoon typology in the light of the EU Water Framework Directive: Italy as a case study. Aquat. Conserv. 16, 457467.

Umgiesser, G., 2000. Modelling residual currents in the Venice Lagoon. In: Yanagi, T., (Ed.), Interactions Between Estuaries, Coastal Seas and Shelf Seas. Terra Scientific Publishing Company (TERRAPUB), Tokyo, pp. 107-124.

Umgiesser, G., Melaku Canu, D., Cucco, A., Solidoro, C., 2004a. A finite element model for the lagoon of Venice, Italy. Development and calibration. J. Marine Syst. 51, 123145.

Umgiesser, G., Sclavo, M., Carniel, S., Bergamasco, A., 2004b. Exploring the bottom stress variability in the Venice Lagoon. J. Marine Syst. 51, 161-178.

Vianello, F., 1981. Aspetti sedimentologici della laguna di Venezia (bacino settentrionale) e del litorale antistante, desunti da analisi granulometriche con 
sedigrafo 5000D. Tesi di Laurea, Università di Padova. 103 pp.

Zonta, R., Guerzoni, S., Pérez-Ruzafa, A., De Jonge, V.N., 2007. Measuring and managing changes in estuaries and lagoons: Morphological and eco-toxicological aspects. Mar. Pollut. Bull. 55, 403-406.

Zuliani, A., Zaggia, L., Collavini, F., Zonta, R., 2005. Freshwater discharge from the drainage basin to the Venice Lagoon (Italy). Env. Int. Special Issue, vol. 31, pp. 929938. 


\section{TABLES}

Table 1. Relevant data for four different morphological sub-basins of LV. Fish-farming areas and unfinished landfill islands not included .

Table 2. Surface area $\left(\mathrm{km}^{2}\right)$ of subtidal flats (year 2000) in four sub-basins of LV, subdivided according to altimetric variation between 1970 and 2000. Strong erosion $=$ bathymetric loss $(\mathrm{BL})$ of $>0.50 \mathrm{~m}$; Moderate erosion $=\mathrm{BL}$ of 0.10/0.50 m; Stability = altimetric difference of $+/-0.10 \mathrm{~m}$; Deposition $=$ altimetric gain of $>0.10 \mathrm{~m} . \mathrm{E} / \mathrm{D}=$ ratio of area affected by erosion (strong+moderate) to area affected by deposition.

Table 3. Mean values and ranges (in brackets) of sedimentary variables in surface sediments of shallow lagoonal flats for four sub-basins; $\mathrm{M}_{\mathrm{z}}=$ mean diameter.

Table 4. Mean values (percentages) of fine sand, very fine sand coarse silt, and fine silt in GM70 and UI00 datasets. Differences between datasets in parentheses.

Table 5. Essential characteristics of four basins of LV (see also Table 1 for other relevant data). 


\section{FIGURE CAPTIONS}

Fig. 1. Simplified morphology of study area (channels: dark blue; shallow flats: light blue; salt marshes: brown) areas marked with dashed lines: fish-farming areas; dotted areas: unfinished landfill islands. City of Mestre and Industrial Zone areas indicated. Location of sampling sites showing coverage by both datasets indicated as follows $\bullet=$ GM70; $\square=$ UI00. Capital letters (A-D) designate sub-basins, from north to south, separated by red lines. Dots with numbers (1-11) indicate freshwater input from mainland (from Collavini et al., 2005).

Fig. 2. Colour-shaded bathymetic maps of LV (left: 1970; right: 2000). Overall increase in depth shown by progressively darker blue colours and migration of $-1.2 \mathrm{~m}$ contour (dotted red line).

Fig. 3. Colour-shaded sedimentation map. Areas of erosion shown by blue shading (dark blue: altimetric differences of <-0.5 m; light blue: from -0.5 to $-0.1 \mathrm{~m})$. Deposition shown by brown shading (altimetric gain of $>0.1 \mathrm{~m}$ ). Stable areas shown in yellow (altimetric difference of between +0.1 and $-0.1 \mathrm{~m}$ ). Inset shows subsidence during past 30 years (from Brambati et al., 2003); blue $=3-5 \mathrm{~cm}$, green $=$ zero.

Fig. 4. Distribution of LV surface areas relative to elevation in 1970 (dashed line) and 2000 (solid line). Note shift of peak from -0.80 to -1.00 , and increase in area deeper than $-1.2 \mathrm{~m}\left(60 \mathrm{~km}^{2}\right.$, grey shading $)$.

Fig. 5. Distribution of LV surface areas relative to elevation in 1970 (dotted line) and 2000 (solid line) within sub-basins A to D (see Fig. 1).

Fig. 6. Average frequency distribution curve of mud in GM70 (dashed line) and UI00 (solid line) datasets within sub-basins A to D. 
Fig. 7. Ternary diagrams of surficial sediments based on sand/silt/clay ratios and on $>63$ $\mu \mathrm{m} / 63-11 \mu \mathrm{m} /<8 \mu \mathrm{m}$ ratios. (a) GM70; (b) UI00. Basin $\mathrm{A}=\bullet$, basin $\mathrm{B}=\square$, basin $\mathrm{C}=\times$, basin $\mathrm{D}=0$.

Fig.8. Spatial distribution of sand in GM70 (a) and UI00 (b) samples.

Fig. 9. Ternary diagrams of surficial sediments in three sub-basins: A, stable, B, affected by moderate erosion and C, affected by strong erosion. 1970: filled symbols; 2000: open symbols. Arrows indicate changes in bottom energy from 1970 to 2000 (a: decreasing; b and c: increasing). 


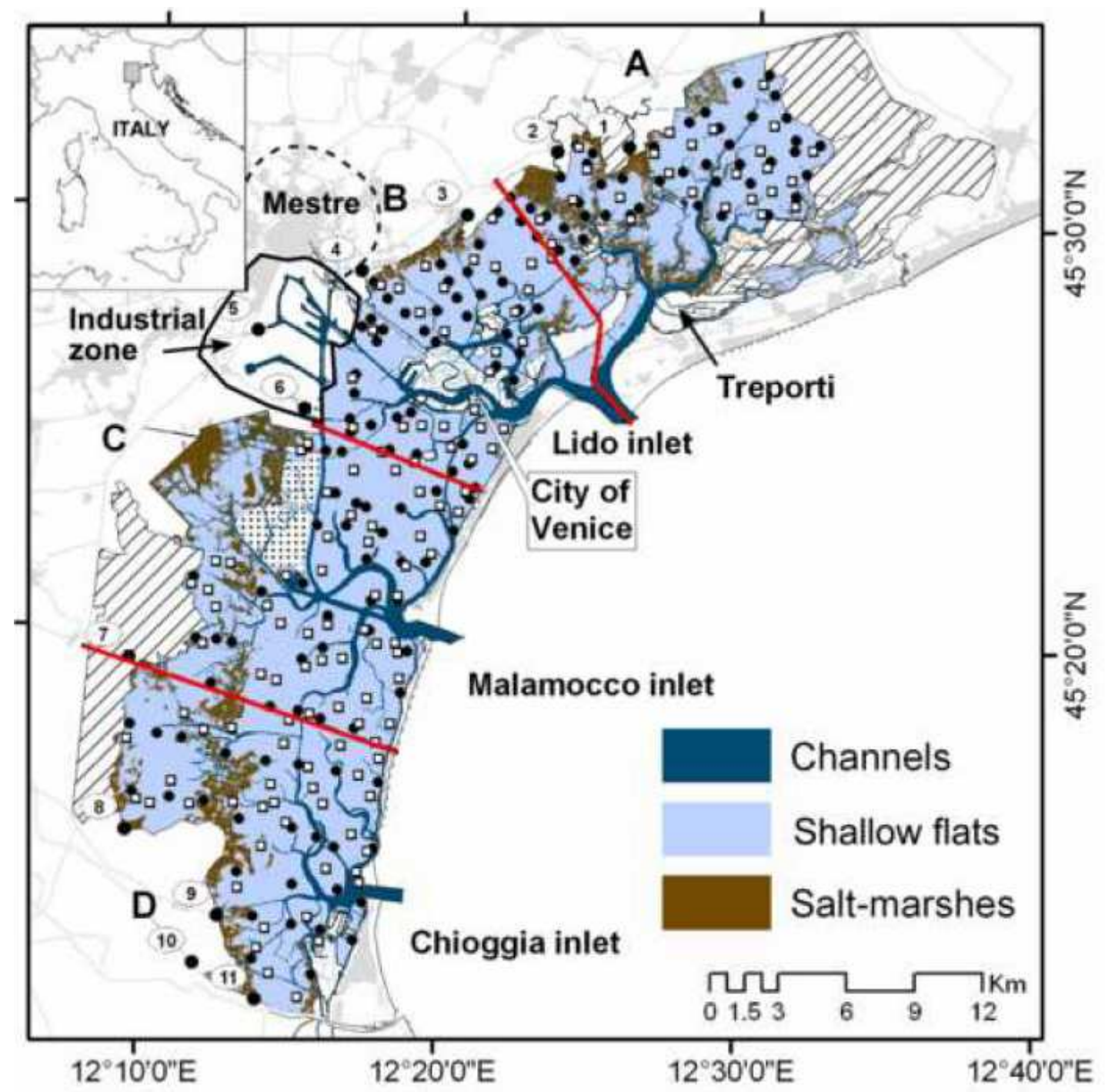

FIG. 1 

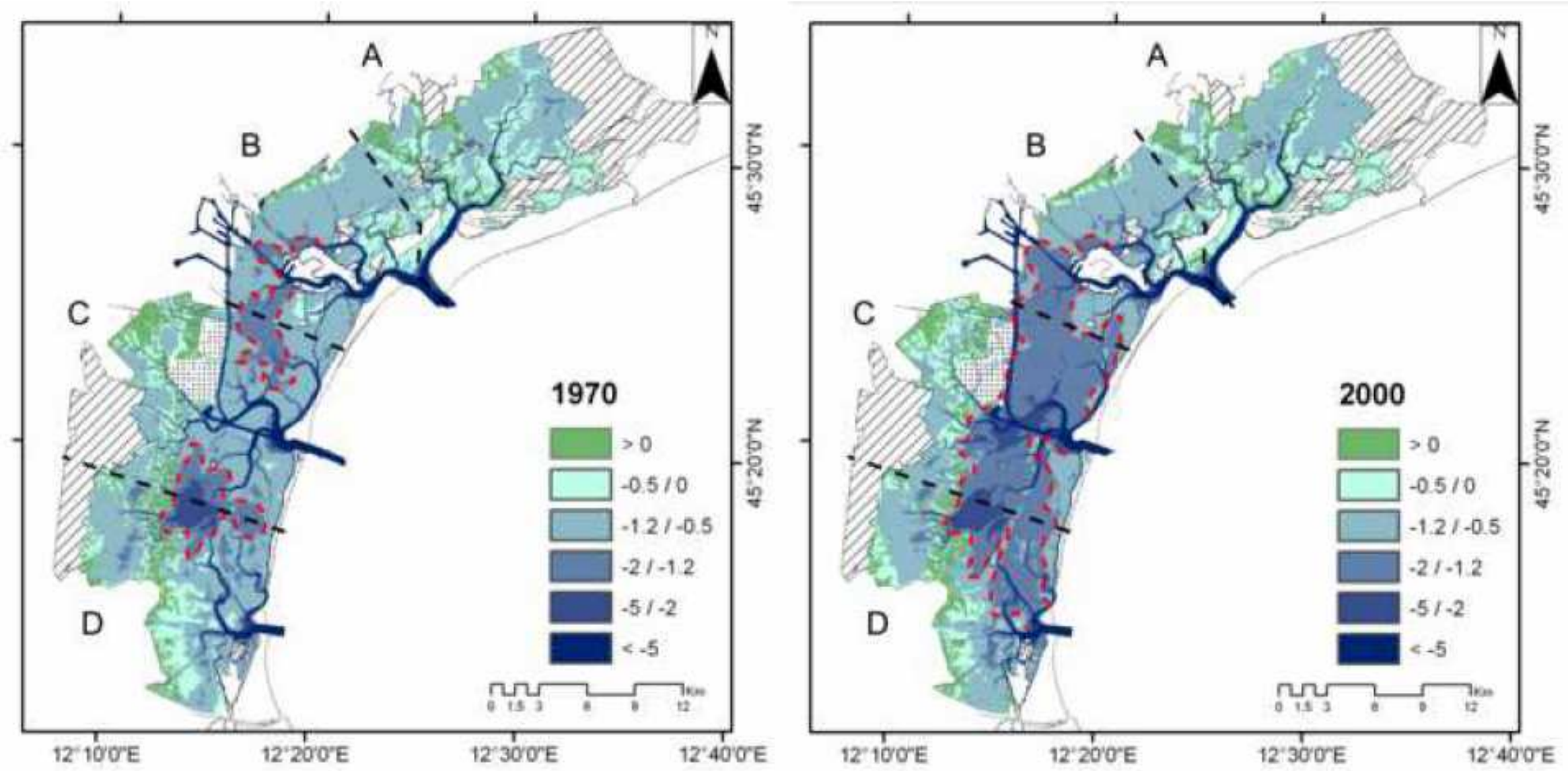

FIG. 2 


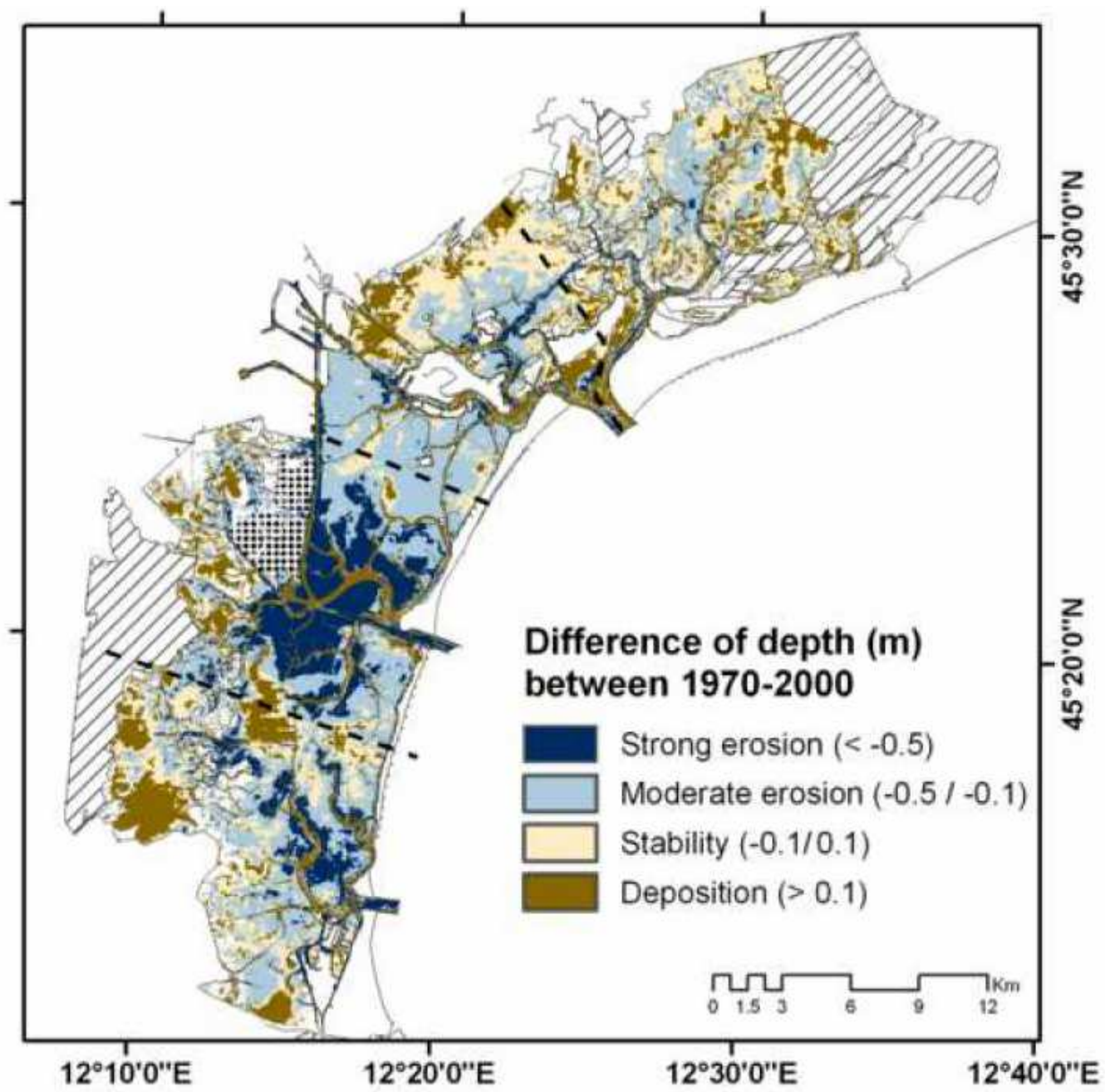

FIG. 3

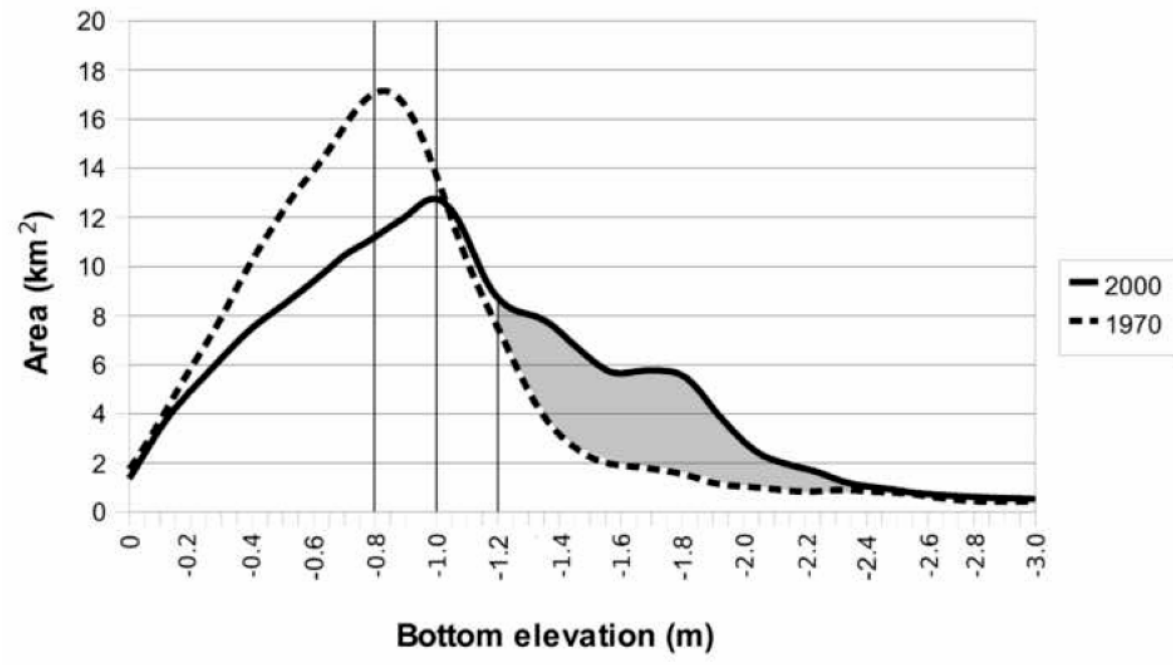

FIG. 4 


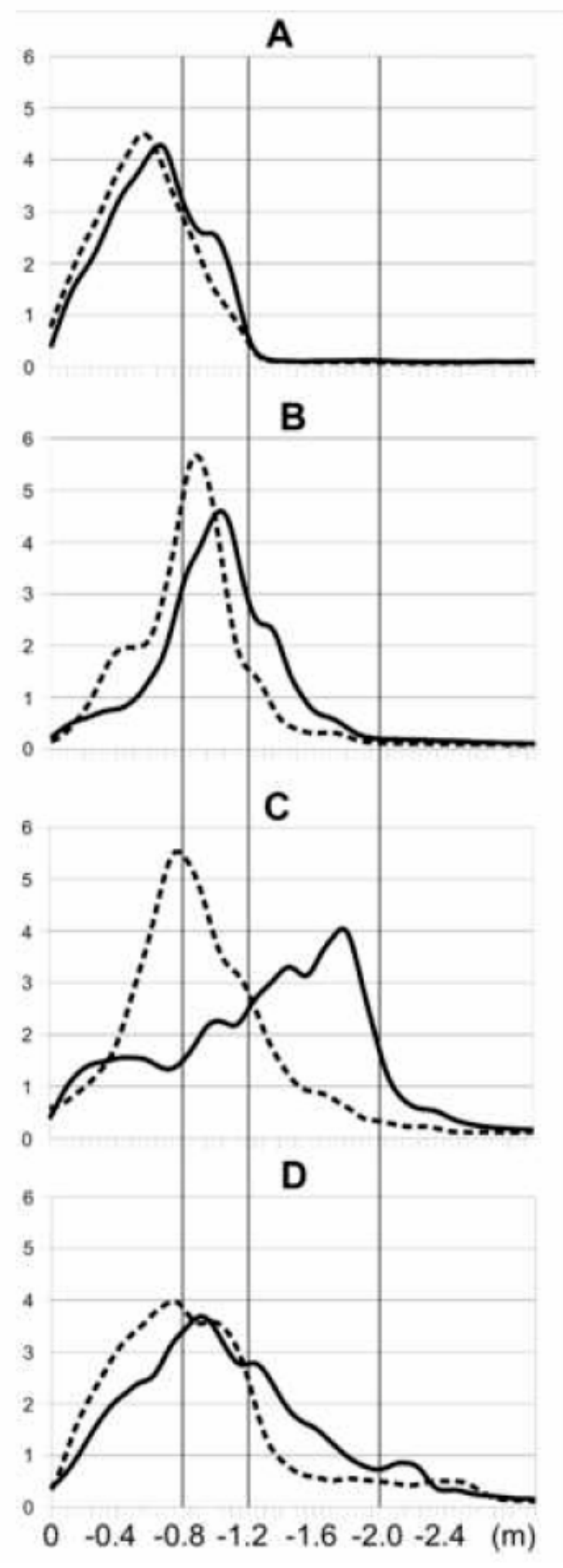

FIG. 5

35 

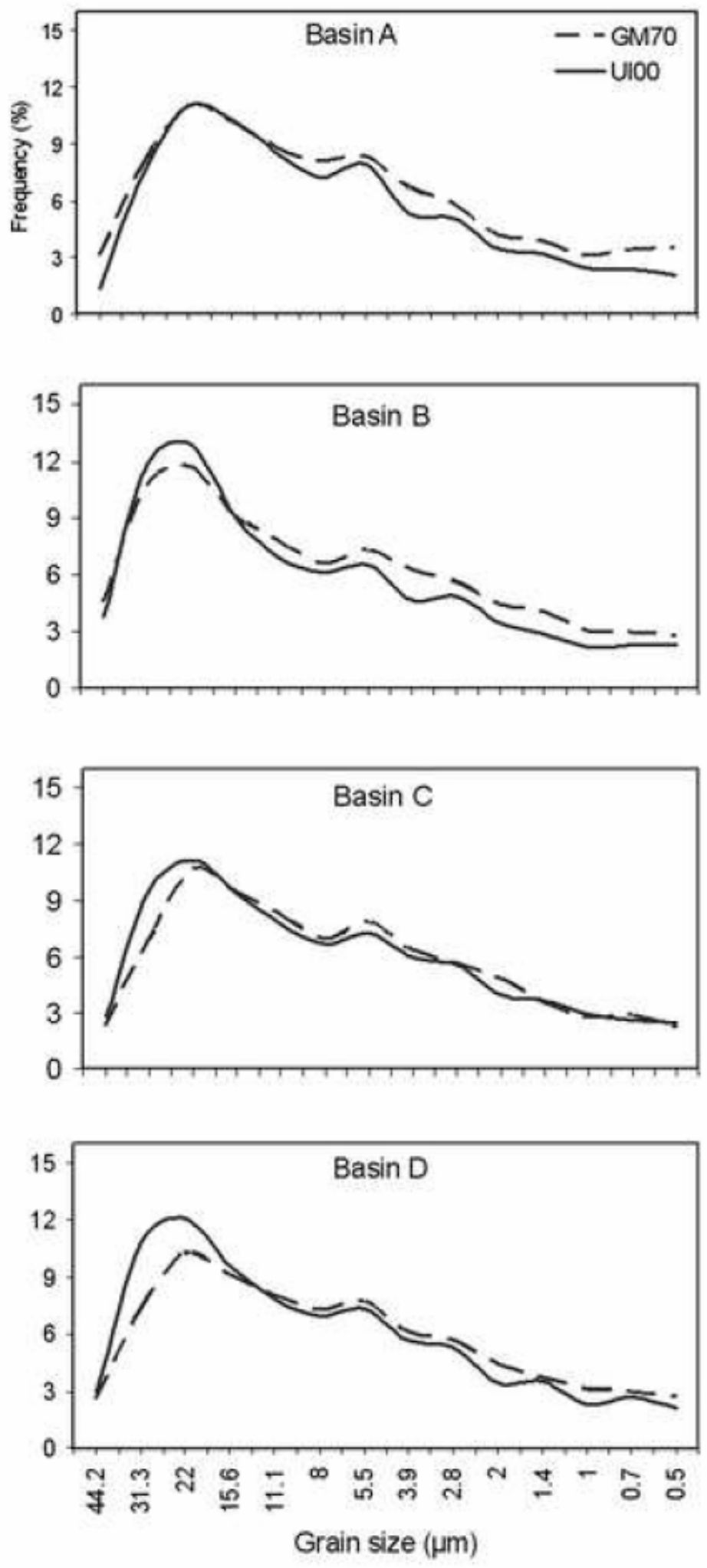

FIG. 6 

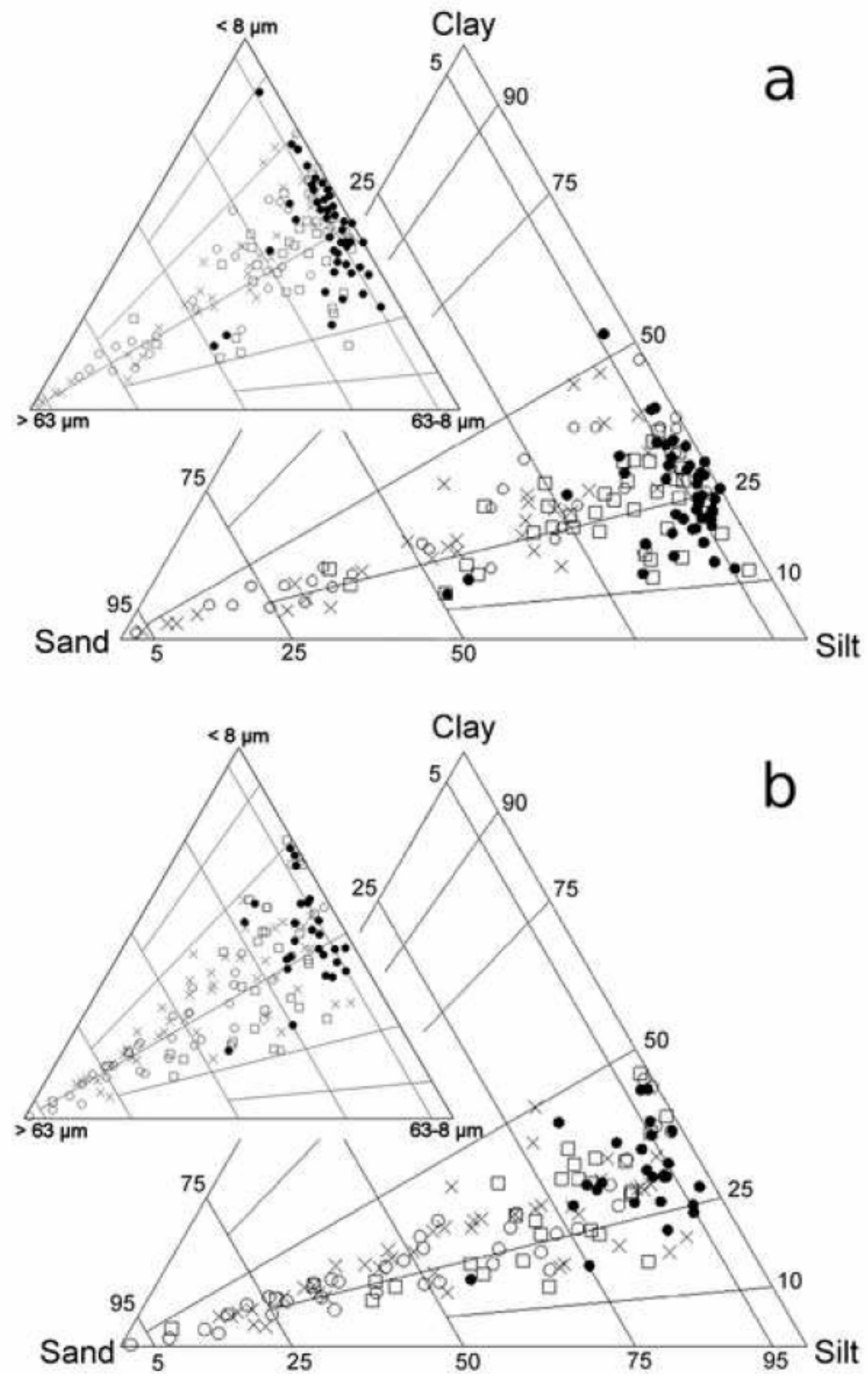

FIG. 7 

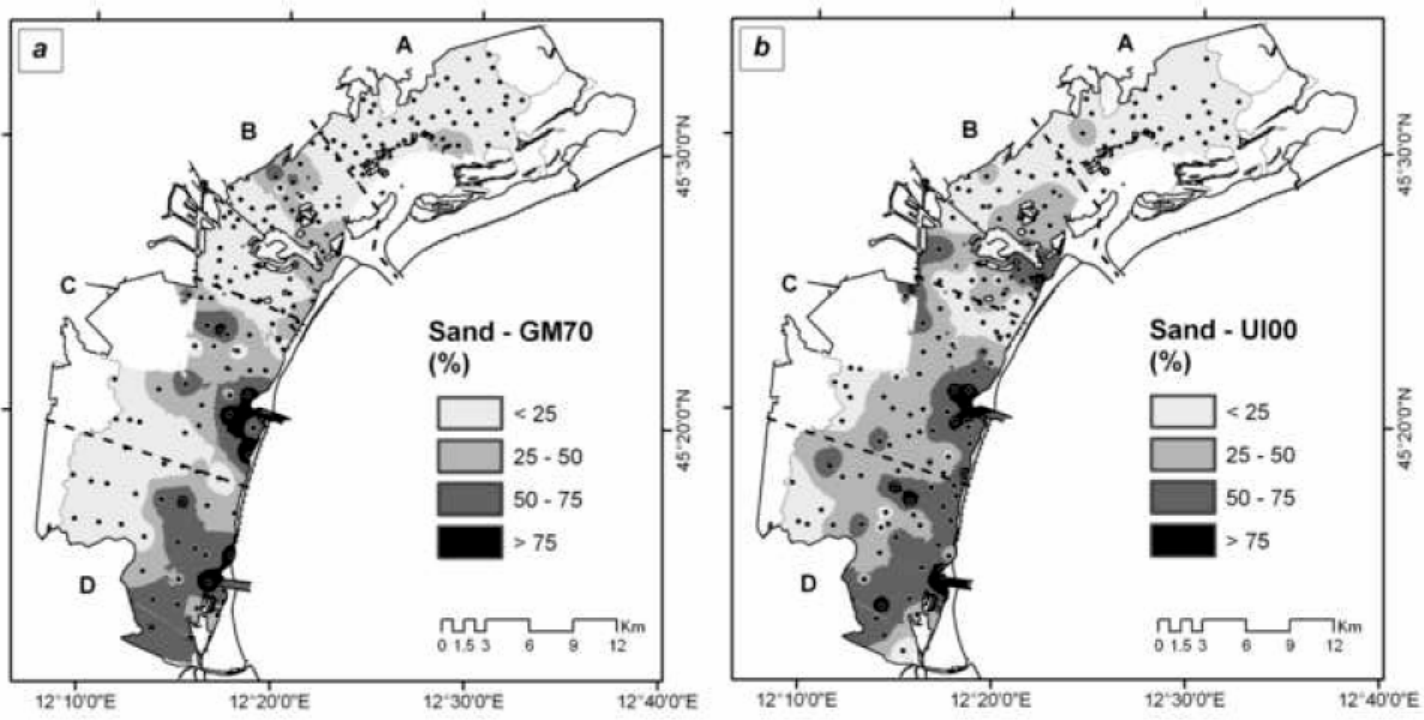

FIG. 8 

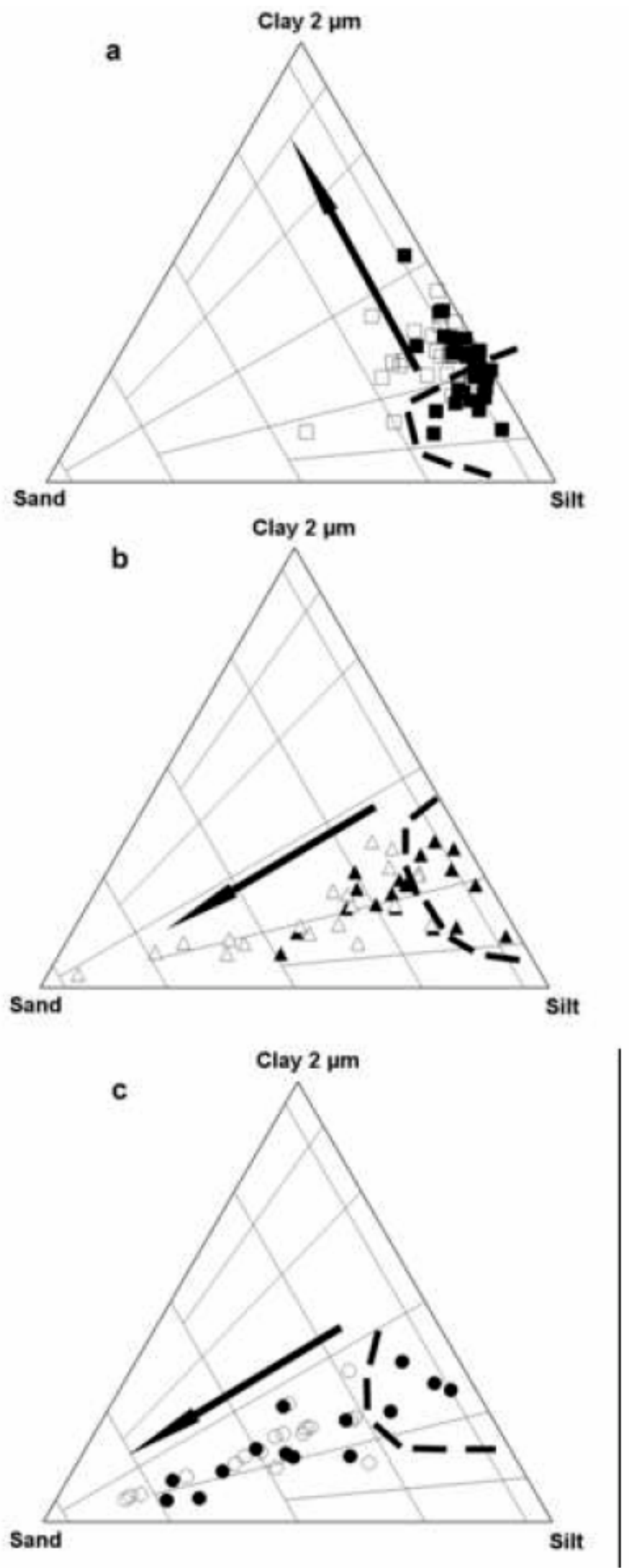

FIG. 9 
Table 1. Relevant data for four different morphological sub-basins of LV. Fish-farming areas and unfinished landfill islands not included .

\begin{tabular}{lcccc}
\hline Basins & $\begin{array}{c}\text { Total } \\
\mathbf{a r e a} \\
\mathbf{k m}^{\mathbf{2}}\end{array}$ & $\begin{array}{c}\text { Salt marshes } \\
\mathbf{k m}^{\mathbf{2}}\end{array}$ & $\begin{array}{c}\text { Shallow bottoms } \\
\mathbf{k m}^{\mathbf{2}}\end{array}$ & $\begin{array}{c}\text { Channels } \\
\mathbf{k m}^{\mathbf{2}}\end{array}$ \\
\hline A: Treporti & 88 & 13 & 64 & 11 \\
B: Lido & 86 & 3 & 66 & 17 \\
C: Malamocco & 121 & 11 & 93 & 17 \\
D: Chioggia & 111 & 13 & 85 & 13 \\
Entire Lagoon & 406 & 40 & 308 & 58 \\
\hline
\end{tabular}

Table 2. Surface area $\left(\mathrm{km}^{2}\right)$ of subtidal flats (year 2000) in four sub-basins of LV, subdivided according to altimetric variation between 1970 and 2000. Strong erosion $=$ bathymetric loss $(\mathrm{BL})$ of $>0.50 \mathrm{~m}$; Moderate erosion $=\mathrm{BL}$ of 0.10/0.50 $\mathrm{m} ;$ Stability $=$ altimetric difference of $+/-0.10 \mathrm{~m}$; Deposition $=$ altimetric gain of $>0.10 \mathrm{~m} . \mathrm{E} / \mathrm{D}=$ ratio of area affected by erosion (strong+moderate) to area affected by deposition.

\begin{tabular}{lccccc}
\hline Basin & $\begin{array}{c}\text { Strong } \\
\text { erosion }\end{array}$ & $\begin{array}{c}\text { Moderate } \\
\text { erosion }\end{array}$ & Stability & Deposition & E/D \\
\hline A & 2 & 18 & 28 & 16 & 1.2 \\
B & 4 & 32 & 19 & 11 & 3.2 \\
C & 32 & 35 & 12 & 13 & 5.1 \\
D & 11 & 30 & 23 & 20 & 2 \\
Total & 49 & 115 & 82 & 60 & \\
\hline
\end{tabular}


Table 3. Mean values and ranges (in brackets) of sedimentary variables in surface sediments of shallow lagoonal flats for four sub-basins; $\mathrm{M}_{\mathrm{z}}=$ mean diameter.

\begin{tabular}{ccccccc} 
& $\begin{array}{c}\text { Sub- } \\
\text { basins }\end{array}$ & $\begin{array}{c}\text { N. of } \\
\text { samples }\end{array}$ & $\begin{array}{c}\text { Sand } \\
(\%)\end{array}$ & $\begin{array}{c}\text { Silt } \\
(\%)\end{array}$ & $\begin{array}{c}\text { Clay } \\
(\%)\end{array}$ & $\begin{array}{c}\mathbf{M}_{\mathbf{z}} \\
(\mu \mathrm{m})\end{array}$ \\
\hline \multirow{3}{*}{ GM70 } & A & 45 & $8(0-49)$ & $68(44-84)$ & $24(8-51)$ & 7.6 \\
& B & 37 & $19(3-64)$ & $60(25-86)$ & $21(8-35)$ & 12.3 \\
& C & 32 & $40(3-96)$ & $41(2-65)$ & $19(1-45)$ & 32.1 \\
& D & 31 & $39(0-97)$ & $42(2-73)$ & $20(1-47)$ & 29.2 \\
\hline \multirow{3}{*}{ UI00 } & A & 26 & $11(2-43)$ & $61(45-72)$ & $29(11-43)$ & 6.1 \\
& B & 29 & $31(1-91)$ & $48(6-70)$ & $22(3-46)$ & 18.4 \\
& C & 44 & $42(6-83)$ & $41(12-73)$ & $18(3-40)$ & 24.5 \\
& D & 37 & $48(1-98)$ & $36(1-62)$ & $16(0-45)$ & 38.3 \\
\hline
\end{tabular}

Table 4. Mean values (percentages) of fine sand, very fine sand coarse silt, and fine silt in GM70 and UI00 datasets. Differences between datasets in parentheses.

\begin{tabular}{cccccc}
\hline & Basin & $\mathbf{> 1 0 5} \boldsymbol{\mu m}$ & $\mathbf{1 0 5 - 6 3} \boldsymbol{\mu m}$ & $\mathbf{6 3 - 2 2} \boldsymbol{\mu m}$ & $\mathbf{2 2 - 2} \boldsymbol{\mu m}$ \\
\hline \multirow{4}{*}{ GM70 } & A & 1 & 6 & 20 & 48 \\
& B & 9 & 10 & 21 & 39 \\
& C & 29 & 11 & 11 & 30 \\
& D & 28 & 11 & 11 & 31 \\
\hline \multirow{4}{*}{ UI00 } & A & $3(2)$ & $7(1)$ & $17(-3)$ & $43(-5)$ \\
& B & $12(3)$ & $18(8)$ & $18(-3)$ & $30(-9)$ \\
& C & $22(-7)$ & $19(9)$ & $14(3)$ & $27(-3)$ \\
& D & $31(3)$ & $17(6)$ & $12(1)$ & $25(-6)$ \\
\hline
\end{tabular}


Table 5. Essential characteristics of four basins of LV (see also Table 1 for other relevant data).

\begin{tabular}{|c|c|c|c|c|}
\hline CHARACTERISTIC & $\mathbf{A}$ & B & $\mathbf{C}$ & $\mathbf{D}$ \\
\hline Particle load (tons $* 10^{3} \mathrm{yr}^{-1}$ ) & 14 & 8 & 4 & 7 \\
\hline Salt-marshes $\left(\mathrm{km}^{2}\right)$ & 13 & 3 & 11 & 13 \\
\hline Salt-marsh disappearance $\left(\mathrm{km}^{2}\right)$ & $\sim 1(10 \%)$ & $0.2(6 \%)$ & $\sim 3(30 \%)$ & $\sim 1(10 \%)$ \\
\hline Erosion/deposition & 1 & 3 & 5 & 2 \\
\hline $\begin{array}{l}\text { Most frequent elevation change } \\
\text { (1970 to 2000, see Fig. 5) }\end{array}$ & $-0.60 /-0.70$ & $-0.90 /-1.10$ & $-0.8 /-1.80$ & $-0.70 /-1.00$ \\
\hline Largest frequency depth shift (m) & 0.10 & 0.20 & 1.00 & 0.30 \\
\hline Grain size changes & $\begin{array}{l}\text { Loss of silt } \\
(63-2 \mu \mathrm{m}) \\
\text { clay-enriched }\end{array}$ & $\begin{array}{l}\text { Loss of silt } \\
(63-2 \mu \mathrm{m})\end{array}$ & $\begin{array}{l}\text { Loss of fine sediment } \\
(<22 \mu \mathrm{m}) \text { and } \\
\text { loss of sand }(>105 \mu \mathrm{m})\end{array}$ & $\begin{array}{l}\text { Loss of mud }(<63 \mu \mathrm{m}) \\
\text { and resedimentation } \\
\text { of sand }(>105 \mu \mathrm{m})\end{array}$ \\
\hline Freshwater forcing & River-dominated & Intermediate & Sea-dominated & Intermediate \\
\hline DEFINITION & $\begin{array}{l}\text { PRISTINE } \\
\text { (TRANSITIONAL- } \\
\text { (NATURAL) }\end{array}$ & $\begin{array}{l}\text { URBAN } \\
\text { (HIGHLY } \\
\text { MODIFIED) }\end{array}$ & $\begin{array}{l}\text { MARINE } \\
\text { (OPEN LAGOON) }\end{array}$ & $\begin{array}{l}\text { EXPLOITED } \\
\text { (SEMI-NATURAL) }\end{array}$ \\
\hline
\end{tabular}


